\title{
Research on the Training Model of English Majors in Colleges and Universities Based on the Needs of Society for "Innovation and Entrepreneurship" Ability
}

\author{
Panpan Li \\ Zaozhuang College, China, ShanDong, Zaozhuang, 277160 \\ 693465046@qq.com
}

\begin{abstract}
Keywords: Innovation and Entrepreneurship; College English; Talent Cultivation
\end{abstract}
\begin{abstract}
With the rapid development of science and technology and economy, the demand for talents in society is not only in explicit professional skills, but also in the invisible ability and quality. However, the English major still has the sameness in the process of personnel training. There are still theoretical and light practices in the cultivation mode and curriculum setting, and talent training is restricted by examinations. It lacks the effective cultivation of students' practical ability and innovation and entrepreneurship. Therefore, how to improve the application skills of English majors through English professional education, and improve the overall quality of college students to meet the needs of talents in new eras and countries is a problem that needs to be solved urgently. This article will adjust the talent training plan for the English majors in the dual-creation training; change the classroom teaching plan and design. Cultivate different grade systems and specifically cultivate the awareness and thinking of innovation and entrepreneurship of English professionals to meet the needs of economic and social development.
\end{abstract}

\section{Introduction}

With the rapid development of Internet information technology and the continuous reorganization and optimization of industries, the disadvantages of university personnel training based on the design of industrial society are increasingly apparent. It does not match the expectation of talents in the knowledge economy society and even restricts the current economic and social development. Compared with the rapid development of other fields, there is no substantive change in the existing homogenization of personnel training for streamline positions. Different colleges and universities in different regions face different levels and interests of students, but still provide the same knowledge and education based on a similar training program at the same pace, and conduct social activities that seem to be lively but do not have too much value. As a result, graduates lack the ability to connect with social development, let alone promote and lead social development. This paper takes the English major of colleges and universities as an example to analyze the lack of innovation and entrepreneurship in the cultivation of English majors, and the reasons for restricting the innovation and entrepreneurship training of English majors. It proposes the following ideas for how English majors in colleges construct and improve the cultivation system for undergraduates' innovation and entrepreneurship: clarify the goal of personnel training; focus on teaching contents and teaching models that are suitable for training to improve innovation and entrepreneurship; encourage students to actively study and strengthen Innovation and entrepreneurship practices guide students to cultivate innovative entrepreneurship, innovative entrepreneurial thinking, and innovative entrepreneurial skills.

\section{Society's Requirements for Training Talents for Innovation and Entrepreneurship}

Higher education designed based on the development of industrial society has been criticized for serving social and economic development. If it is considered out of touch with society, the knowledge education provided by it is actually out of touch with society. The connection between universities and society lies in the cultivation of talents. Because the subject knowledge system that 
universities rely on is a relatively closed internal circulatory system, the response to new developments and new demands in economic and social development lags behind, resulting in the provision of a training system that lags behind social needs. Moreover, the development of many undergraduate institutions is vague. Although there are divisions of applied-type undergraduate colleges, teaching-research-oriented universities, and research universities, applied-type colleges and teaching-research universities are all keeping knowledge education. Although many institutions have adjusted their courses and increased competitions and activities at all levels and various disciplines, they have low levels and small scope. Eventually, they are inevitably subject to formality and lack realism and innovation. Innovation and entrepreneurship education and disciplines are always two skins, failing to form an innovation and entrepreneurship education system.

Innovation and entrepreneurship education emphasizes the integration of teaching, learning and doing. Its core is to build a modern higher education model oriented on cultivating innovative and entrepreneurial talents, to guide teachers and students in the school to continuously iterate educational concepts, deepen education and teaching reform, and to closely integrate talent cultivation, scientific research, and social services, from a focus on knowledge education to a focus on innovation and entrepreneurship development. Therefore, local colleges and universities must change education and teaching methods, respect students' subject status and individual differences, follow growth laws, guide independent thinking, spontaneous and independent exploration, and cultivate innovative consciousness, innovative spirit, and entrepreneurial skills. Colleges and universities need to integrate double-creation education into the whole process of personnel training in universities. The core goal is to cultivate dual-creation talents. Taking the cultivation of double-creating talents as the core goal and the growth law of innovative talents as the basic rationale, the quality of innovation and entrepreneurial talents training as the evaluation criteria, based on the double-creation personnel training framework to plan and promote various tasks.

According to the differences between the double-education education objects, the current innovation and entrepreneurship education model can be divided into focusing and diverging, the former focusing on depth, while the latter emphasizes coverage. Focusing does not target all groups of college students. Instead, it focuses on the selective cultivation of undergraduates who have strong creative entrepreneurial aspirations and potential, or provide guidance, support, and promotion for creative ideas or projects that have industrialization potential. The divergence model targets college students as a whole and faces all students to popularize innovation and entrepreneurship education. The two modes are not either one or the other and are not mutually compatible. On the contrary, they can also promote each other. Diversified innovation and entrepreneurship training can broaden the awareness and cultivate potential, help to focus on the advantages of resources to achieve a breakthrough, so as to back-fed divergent and double inspiration to stimulate enthusiasm. Therefore, all students in the English language major can first gain introductory knowledge, and then concentrate their guidance according to their will, potential and characteristics. In the general improvement of double-creation awareness, thinking and ability, while cultivating innovative entrepreneurial English professionals who meet the needs of society.

\section{Problems in the Cultivation of Innovative English Majors in Colleges and Universities}

Teacher Skills need to be Strengthened. At present, the introduction of teachers in colleges and universities is mainly based on academic qualifications and scientific research results. Most college English teachers are autonomously trained in China, and they have not received the general education. They generally lack the knowledge structure and do not have the interdisciplinary knowledge ability. Although this phenomenon has changed, most teachers directly engage in teaching work after graduating from colleges. They lack social practice and entrepreneurial training. Innovation and entrepreneurship is also a new thing for them. College English teachers generally lack the ability to innovate and instruct students. In addition, teachers generally have a large amount of teaching workload, heavy scientific research tasks, and they are busy with the promotion of academic qualifications and the promotion of professional titles. Innovation and entrepreneurship 
guidance is often " touching on something without going into it deeply" and " individual combat" and it lacks systematic and scientific management.

Curriculum System is not Systematic Enough and Perfect. In the curriculum system setting, some schools are too focused on teaching theoretical knowledge, ignoring the practical ability, especially the cultivation of innovation and entrepreneurship. The entrepreneurship education in colleges and universities is mainly limited to the direction of guidance and the construction of innovation and entrepreneurship bases. In the training of personnel training courses and training, students' ability in innovation and entrepreneurship cannot be improved, resulting in the emergence of students who want to start a business. However, they do not know how to start or lack of good guidance and the lack of knowledge and practical ability to make innovation and entrepreneurship a phenomenon of empty talk. In teaching, there is a lack of ability to train students of English majors in thinking. Classroom teaching and practical teaching tend to stay in the past of duck-type teaching, blindly emphasize the inculcation of knowledge and the improvement of language skills, ignoring students' ability to think. Students are still excessively dependent on teachers. The student's brain becomes a "knowledge warehouse," and there is no way to "discover problems and solve problems".

Single Student Knowledge Structure. From the perspective of traditional teaching methods and methods, in the process of constructing English majors' knowledge system, teachers' lectures take up a lot of time and hours, teachers are still the main body of teaching, and students are still the recipients of teaching. In today's information age, many professional knowledge can be obtained through multiple channels. Teachers should plan and build their knowledge structure for students and teach them how to acquire knowledge. Students are required to learn the required knowledge in advance, effectively use limited teaching time, and focus more on student understanding and analysis of knowledge, turning students into teaching centers. From the perspective of knowledge structure, the traditional English major teaching mainly involves history, religion, culture, literature, art, legal basis and other humanities and social sciences. After graduating, students' employment units tend to have natural science backgrounds such as companies and companies. For some employers, they tend to choose non-English majors who have strong science and technology backgrounds and strong English skills. This results in English majors Employment and entrepreneurship are in a very awkward position. Some colleges and universities also reformed the talent training model and proposed an "English + "professional training model. They hope to broaden students' knowledge area. However, due to the lack of clear direction and the lack of initiative of students, their knowledge structure has still not been significantly improved.

\section{Training Mode of Innovation Talents Cultivation for English Majors in Colleges and Universities}

The Construction of College English Professionals Innovation and Entrepreneurial Education Platform. The essence of innovation and entrepreneurship education in colleges and universities is to cultivate students' creative thinking, expand their entrepreneurial concepts, and improve their entrepreneurial ability. And to a certain extent, they can consciously shape the capabilities of their managers and leaders. The ultimate goal of the innovation and entrepreneurship training of English majors in universities in China is through innovative and entrepreneurial talent cultivation models, so that college graduates can become successful job seekers and gradually become providers of market positions. Therefore, if we want to successfully carry out talent innovation and entrepreneurship education, we must build an education platform that incorporates the guiding ideology of innovation and entrepreneurship. In the process of teaching English majors, general education courses related to innovation and entrepreneurship can be set up to purposefully cultivate the creative and entrepreneurial thinking of college students. Then set up innovative entrepreneurship courses related to market demand positions for English majors. Through the understanding of the needs of companies or companies in English majors, targeted and innovative courses related to innovation and entrepreneurship are designated. At the same time, some logical thinking courses should be set up to enhance their entrepreneurial invisible capabilities through 
training students' thinking ability.

Construction of English Innovation and Pioneering Practice Platform for College English Majors. The final result of the cultivation of innovation and entrepreneurship education for English majors in colleges and universities is still to be tested through practice. By building a platform for innovation and entrepreneurship practice, the combination of theory and practice, production, education and research are combined to further deepen the students' ideas of innovation and entrepreneurship and improve their practical ability.

(1) According to the actual situation of the students, you can set up business start-up classes, intermediate classes and advanced classes. Different entrepreneurial projects with different difficulty levels are set up in different classes. For example, the primary business class is mainly to enhance students' entrepreneurial experience. Simple entrepreneurial activities can be set up to encourage students to independently study relevant entrepreneurial theories according to their own interests and interests, and to increase their entrepreneurial awareness and risk awareness. The Advanced Class for Entrepreneurship allows students to choose their own entrepreneurial projects, use their basic theories, and set goals for their entrepreneurial projects, specific project operating procedures, and project projected benefits calculations to improve students' abilities in innovation and entrepreneurship.

(2) Carry out simulated innovation and entrepreneurship competitions. Conduct simulated entrepreneurship competitions for English professionals and encourage students to formally participate in group registration. Through the rational division of labor within the group, the entire virtual project can be completed. For example, to carry out the virtual international logistics competition, each project team provides a certain amount of virtual funds, and achieves the maximum profit by conducting related commodity transactions. Teachers can provide active theoretical and practical guidance during the completion of the entire project, and specific operations must be completed by the team themselves. This will not only increase students' awareness of entrepreneurship and risk, but also increase their entrepreneurial practice ability and increase their team awareness.

Taking School-enterprise Cooperation as an Opportunity to Improve the Quality of "Double Teachers". School-enterprise joint training refers to the signing of a talent training agreement between the school and the enterprise, and the joint formulation of a talent training plan to train specialized talents that meet the needs of the enterprise, namely "order class". School-enterprise entity cooperation can be either sponsored by the company to build an on-campus training room, or it can be provided by the school to introduce some of the company's service links to schools. For example, English majors can form "translating workshops" in the senior year, cooperate with well-known translation companies, and solve some of the company's business under the guidance of the university's mentors. In addition, the training institutions and the backbone of the company are employed as part-time teachers to undertake the teaching of some professional courses or to participate in the practice of guiding professional courses. Regularly hire industry elites to hold lectures for students, hold discussions with students, and teach students the latest workplace information. Only if the quality of teachers improves, will the student's innovation and entrepreneurial ability have more room for improvement.

\section{Summary}

Although the English majors of universities and colleges have carried out significant reforms and practices on the talent cultivation model, the training model and curriculum system setting for college English majors are still relatively traditional. They are basically set according to the English language curriculum system, and their focus remains on language. In terms of skills, students' enthusiasm and innovation ability are neglected. Under this mode of cultivation, it is easy to cause situations in which teaching and thinking, innovation and other practical activities are out of touch. Therefore, English majors in colleges and universities need to accurately position personnel training, clearly cultivating goals; make adjustments in curriculum settings, inject new curriculum elements, and adapt to students' development needs; reform teaching content and teaching methods, and 
highlight and emphasize innovations' entrepreneurial ability training, combined with English professional skills, to expand the school professional; in the innovation and entrepreneurship practice, provide students with a large number of practical opportunities to strengthen the guidance of students. Only in this way can we cultivate English professionals who meet the needs of society and have innovative and entrepreneurial skills.

\section{References}

[1] Lin X. Hospitality Information Reading Innovation for Tourism English Major[J]. Journal of Sichuan Engineering Technical College, 2013.

[2] Wang T. Design and innovation of the curriculum evaluation system of the business English major[J]. Journal of Nanchang College of Education, 2013.

[3] Zhang W, Feng G. Planning an Innovation-cultivating Curricular Module for English Major Education[J]. Foreign Languages \& Their Teaching, 2015.

[4] Zhang Y J. The Reform and Innovation of Comprehensive English for English Majors in Teacher's College[J]. Journal of Anhui University of Technology, 2011.

[5] Shi Y, Duan Y, Xiang G. A Decision Making Analyzing Mode for Opportunity Factors from Major Environmental Risks in an Enterprise's Sustainable Innovation Process[M]// Proceedings of the Seventh International Conference on Management Science and Engineering Management. Springer Berlin Heidelberg, 2014:1325-1335.

[6] Jeong-Gon Kim, Seung Kwon Na, Jong-Moon Jang, et al. : (Digital Innovation and Policy Challenges: Focused on Major Countriess Cases and Their Implications)[J]. Policy Analyses, 2016.

[7] Zhang W. The research and practice of English-Major cultivation mode based on collaborative innovation in university of science and engineering: taking Kunming University of Science and Technology for example[J]. Journal of Jiamusi Vocational Institute, 2016.

[8] Zhang W, Feng G. Planning an Innovation-cultivating Curricular Module for English Major Education[J]. Foreign Languages \& Their Teaching, 2015.

[9] GUO Jin-ping, PAN Jun-feng, Foreign Language School, et al. Innovative Attempts on English Major Phonetics Teaching[J]. Overseas English, 2015.

[10] Chen L. The Current Situation and Countermeasures of Practical Teaching of Business English Major in Higher Vocational Colleges[J]. Journal of Jiamusi Vocational Institute, 2017.

[11] Yong Y I, Department E. Research on the Development of Foreign Languages Majors under the Mode of Collaborative Innovation Based on the Construction of Specialty Clusters in Higher Vocational Colleges[J]. Journal of Shaoguan University, 2015.

[12] Ding L, Economics S O. A Research on New Path of Business English Discipline Construction[J]. Journal of Inner Mongolia Normal University, 2017.

[13] Xiao F L, Vocationalamp L. Research and Practice of Vocational Colleges' Business English Professional Curriculum System Innovation Based on Working Process[J]. Journal of Shandong Agriculture \& Engineering University, 2015.

[14] Ravanelli M, Omologo M. The DIRHA-English corpus and related tasks for distant-speech recognition in domestic environments[J]. 2017. 